\title{
Expression of inducible nitric oxide synthase, caspase-3 and production of reactive oxygen intermediate on endothelial cells culture (HUVECs) treated with $P$. falciparum infected erythrocytes and tumour necrosis factor- $\alpha$
}

\author{
Loeki Enggar Fitri
}

\begin{abstract}
Abstrak
Cytoadherence eritrosit terinfeksi P.falciparum pada sel endotel adalah faktor utama dalam perkembangan malaria berat. Proses ini diduga melibatkan respon imun lokal yang distimulasi oleh Tumour Necrosis Factor- $\alpha$ (TNF- $\alpha$ ). Penelitian ini dilakukan untuk mengetahui pengaruh Cytoadherence eritrosit terinfeksi P.falciparum dan pemberian TNF- $\alpha$ dalam menginduksi aktivasi sel endotel secara in vitro. Ekspresi inducible Nitric Oxide Synthase (iNOS) dan Caspase-3, serta produksi Reactive Oxygen Intermediate (ROI) digunakan sebagai parameter aktivasi. Suatu penelitian eksperimental laboratorium telah dilakukan untuk melihat aktivasi sel endotel (HUVECs) setelah dipajan dengan TNF- $\alpha$ selama 20 jam atau eritrosit terinfeksi P.falciparum selama 1 jam atau keduanya. Biakan sel endotel normal digunakan sebagai kontrol. Dengan metode imunohistokimia respon imun lokal dari sel endotel ditentukan dengan melihat ekspresi iNOS dan Caspase 3. Nitro Blue Tetrazolium reduction-assay dilakukan untuk melihat produksi ROI secara semikwantitatif pada sel endotel. Ekspresi iNOS hanya ditemukan pada biakan sel endotel yang dipajan dengan eritrosit terinfeksi P.falciparum atau eritrosit terinfeksi P.falciparum bersama TNF- $\alpha$. Ekspresi Caspase 3 terlihat tipis pada beberapa sel pada biakan endotel normal. Ekspresi ini meningkat secara signifikan pada biakan sel endotel yang dipajan eritrosit terinfeksi P.falciparum bersama TNF- $\alpha(p=0,000)$. Sel endotel normal yang diinduksi dengan suatu induktor non spesifik (PMA) mengeluarkan ROI dalam kadar yang sangat rendah. Pemberian eritrosit terinfeksi P.falciparum saja atau eritrosit terinfeksi P.falciparum bersama TNF- $\alpha$ menyebabkan sel endotel mengeluarkan ROI dalam kadar medium sampai tinggi. Pajanan eritrosit terinfeksi P.falciparum dan TNF- $\alpha$ pada sel endotel dapat menginduksi respon imun lokal yang ditandai dengan peningkatan inducible nitric oxide synthase dan pelepasan radikal bebas sehingga menyebabkan kerusakan sel. (Med J Indones 2006; 15:151-6)
\end{abstract}

\begin{abstract}
Cytoadherence of $P$. falciparum infected erythrocytes on endothelial cells is a key factor in development of severe malaria. This process may associated with the activation of local immune that was enhanced by Tumour Necrosis Factor- $\alpha$ (TNF- $\alpha$ ). This study was conducted to see the influence of P.falciparum infected erythrocytes cytoadherence and TNF- $\alpha$ treatment in inducing endothelial cells activation in vitro. Inducible Nitric Oxide Synthase (iNOS) and Caspase-3 expression, also Reactive Oxygen Intermediate (ROI) production were used as parameters. An Experimental laboratory study had been done to observe endothelial cells activation (HUVECs) after treatment with TNF- $\alpha$ for 20 hours or P.falciparum infected erythrocytes for 1 hour or both of them. Normal endothelial cells culture had been used as a control. Using immunocytochemistry local immune activation of endothelial cells was determined by iNOS and Caspase-3 expression. Nitro Blue Tetrazolium reduction-assay was conducted to see the ROI production semi quantitatively. Inducible Nitric Oxide Synthase expression only found on endothelial cells culture treated with P.falciparum infected erythrocytes or both P.falciparum infected erythrocytes and TNF- $\alpha$. Caspase-3 expression found slightly on normal endothelial cells culture. This expression increased significantly on endothelial cells culture treated with both P.falciparum infected erythrocytes and TNF- $\alpha$ $(p=0,000)$. The normal endothelial cells release low level of ROI in the presence of non-specific trigger, PMA. In the presence of P.falciparum infected erythrocytes or TNF- $\alpha$ or both of them, some cells showed medium to high levels of ROI. Cytoadherence of P. falciparum infected erythrocytes and TNF a treatment on endothelial cells can induce activation of local immune marked by increase inducible nitric oxide synthase and release of free radicals that cause cell damage. (Med J Indones 2006; 15:151-6)
\end{abstract}

Keywords: P.falciparum ,HUVECs, TNF- $\alpha$, iNOS, Caspase-3, ROI

Department of Parasitology, Medical Faculty, Brawijaya University, Malang, Indonesia
Severe Plasmodium falciparum malaria is accompanied by systemic endothelial activation represented by the upregulation of Tumour Necrosis Factor- $\alpha$ (TNF- $\alpha)$, inducible Cell Adhesion Molecule and cytoadherence 
process which increases sequestration of parasitized erythrocytes on endothelial cells of vital organ. ${ }^{1}$

Although sequestration of parasitized erythrocytes on microvascular is necessary for development of anoxia and organ damage, but local immune might be the more important factor for neurotoxicity. ${ }^{2}$

Study on murine endothelial cells had been revealed that Interferon gamma (IFN- $\gamma$ ), in combination with TNF- $\alpha$ and Interleukiun-1 (IL-1) or Lypopolysacharida (LPS) can generate Nitric Oxide. ${ }^{3}$ But no study had been reported to see the effect of cytoadherence of $P$.falciparum infected erythrocytes in inducing local free radicals and programmed cell death on human endothelial cells.

The objective of this study was to see the influence of cytoadherence of P.falciparum infected erythrocytes and TNF- $\alpha$ treatment in endothelial cells activation in vitro. iNOS and Caspase-3 expression, also ROI production were used as parameters.

\section{METHOD}

An experimental study with complete random design was used in this research. Using normal endothelial cells culture (HUVECs) as control group, another treatment group of HUVECs had been exposed 20 hours with TNF $\alpha$ dose $32 \mathrm{pg} / \mathrm{ml}$, and the other had been exposed 1 hour with $P$. falciparum infected erythrocytes (Malang isolated). The last group had been exposed with both $\mathrm{TNF} \alpha$ and $P$. falciparum infected erythrocytes.

Expression of iNOS and caspase 3 on endothelial cells culture had been detected by immunocytochemistry staining using iNOS monoclonal antibody (InnoGenex) and caspase-3 monoclonal antibodi (Santa Cruz). ROI production was determined semi quantitatively by using NBT Reduction-assay.

\section{Malaria culture $^{4}$}

Collect $2 \mathrm{ml}$ of venous blood into heparinized tubes. Centrifuges at $3000 \mathrm{rpm}$ for 10 minutes, wash the cells twice in HEPES-buffered RPMI 1640 (GIBCO BRL) and then carefully remove the whole buffy coat. Adjust to $2 \%$ hematocrite in complete malaria culture medium RPMI-HEPES supplemented with $2 \mathrm{mM}$
L-glutamine, $10 \%$ heat-inactivated $\mathrm{AB}$ human serum, 0,25\% NaHCO3, 5 IU Penicillin and $5 \mu \mathrm{g} / \mathrm{ml}$ Streptomycin. Set up the parasite cultures in tissue culture flask in candle jar $37^{\circ} \mathrm{C}, 5 \% \mathrm{CO}_{2}$ for $24-48$ hours.

\section{Endothelial Cells (HUVECs) Culture ${ }^{5}$}

Endothelial cells were obtained from human umbilical veins and cultured in M199 medium (GIBCO, Paisley, UK) $\mathrm{pH} 7,4$ containing $25 \mathrm{mM}$ HEPES, 10\%-heat inactivated Fetal Bovine Serum, $100 \mathrm{ug} / \mathrm{ml}$ Endothelial Cell Growth Factor (Biochemical Supplies, Bethesda, $\mathrm{MD}), 10 \mu / \mathrm{ml}$ heparin and $20 \mathrm{ug} / \mathrm{ml}$ gentamycin.

\section{Cytoadherence Assay ${ }^{4}$}

Endothelial culture in plate 6-well were prepared 3648 hours before assay, or at approximately $80 \%$ confluency. Medium were removed and cells were washed with binding medium, then overlaid with malaria culture with a parasitemia exceeding $8 \%$ at a hematocrit $2-3 \%$ in binding medium. Incubate at $37^{\circ} \mathrm{C}$ for 1-1,5 h. Resuspend the erythrocytes by gently rocking the flask every $15 \mathrm{~min}$. Unbound erythrocytes were removed by washing the cells 3 times with binding medium. The cells culture were fixed with $0,2 \%$ glutraldehyde and stained with Giemsa $10 \%$, then checked with microscope 400x to see the percentage of cytoadherence.

\section{Giemsa staining ${ }^{4}$}

After fix the coverslip with $0,2 \%$ glutaraldehyde, leave it to dry in an incubator at $37^{\circ} \mathrm{C}$ for 1 hour. Prepare a fresh $10 \%$ Giemsa in phosphate buffer $(\mathrm{PH} 7,1)$ and pour the Giemsa solution on well containing coverslip. Leave to stain for 20 minutes. Rinse carefully with water. Mount coverslips on slide and let it dry.

\section{Immunochemistry staining for iNOS dan ICAM- 1expression $^{6}$}

Monolayer endothelial cells from control and treatment groups were washed with PBS three times and fixed with methanol. Peroxidase $\left(\mathrm{H}_{2} \mathrm{O}_{2}\right)$ was added for 20 minutes. Wash again with PBS three times then blocking with serum for 20 minutes. Monoclonal antibody against ICAM-1 or iNOS was added to the cell over night at room temperature $\left(2^{\circ}-8^{\circ} \mathrm{C}\right)$. Cells were then washed 
three times in PBS, before adding Biotinilyze goat anti-mouse immunoglobulin (DAKO) for 1 hour. HRP SA (Horse Radish Peroxidase Strep-Avidin) was added for 40 minutes. Washed in PBS three times and then stained with Amino Ethyl Carbazole (AEC). After incubating for 10 minutes, cells were then washed in water, counterstaining with Mayer Haematoxylin for 2 minutes. The coverslips mounted on glass slides.

\section{ROI Assay ${ }^{7}$}

The ability of endothelial cells to undergo an oxidative burst was measured by the superoxide anion $\left(\mathrm{O}_{2}{ }^{-}\right)$ dependent reduction of Nitroblue Tetrazolium (NBT) to insoluble formazan precipitate. After washing in PBS, 50 ul PMA 1250 ng/ml, 400 ul NBT $1 \mathrm{mg} / \mathrm{ml}$, and $45 \mathrm{ul} \mathrm{HBSS}$ were added to monolayer endothelial cells from control and treatment groups. Control wells received only NBT solution and HBSS. To conform if the precipitate was ROI, 5 ul SOD 3.000 unit was added to another wells. Incubate for 60 minutes at incubator $37^{\circ} \mathrm{C}, 5 \% \mathrm{CO}_{2}$. Cells were washed in PBS

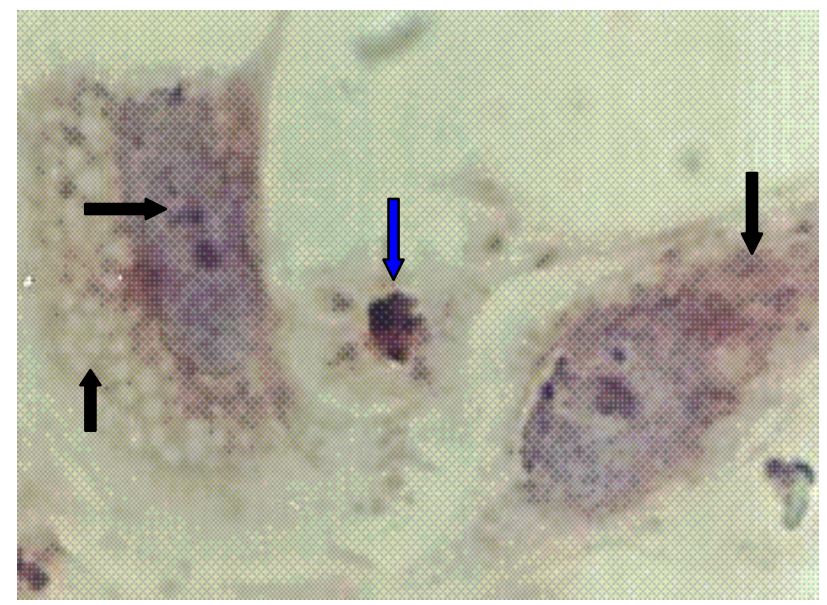

(A) and fixed with methanol for 5 minutes. After washing in PBS, 2\% Neutral red solution was added to each well and after 15 minutes the cells were washed with distilled water, air dried and the coverslips mounted on glass slides.

\section{RESULT AND DISCUSSION}

Inducible Nitric Oxide Synthase (iNOS) expression that showed as a red stain on cell membrane and cell cytoplasma only found on endothelial cells culture treated with P.falciparum infected erythrocytes or both P.falciparum infected erythrocytes and TNF- $\alpha$. The intensity of the this expression range from low to medium (+ to +++) (Figure 1). Inducible Nitric Oxide Synthase (iNOS) expression did not find on endothelial cells that treated with TNF- $\alpha$ only. Using $t$ test, there was a significant difference in iNOS expression between cells which were treated with P.falciparum infected erythrocytes and endothelial cells culture treated with both P.falciparum infected erythrocytes and TNF- $\alpha(\mathrm{p}=0,000)$.

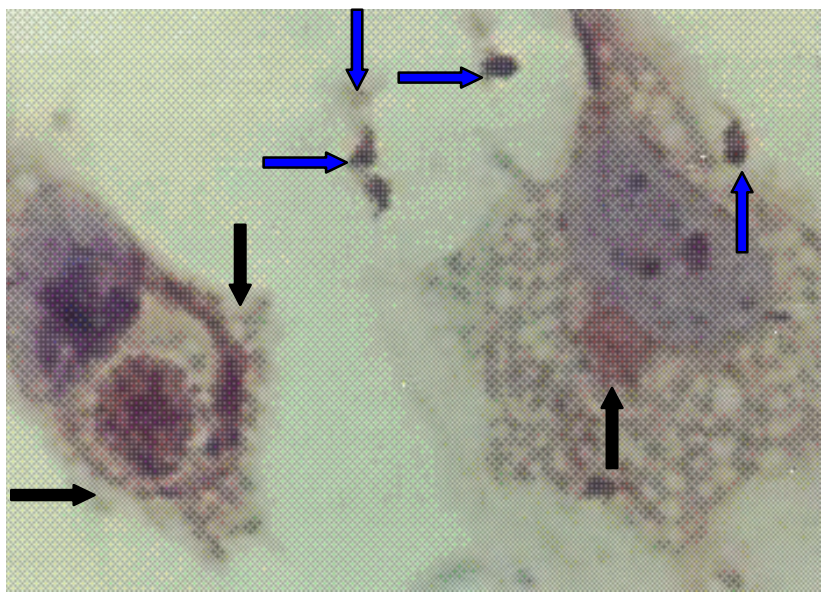

(B)

Figure 1. The black arrow show an iNOS expression on endothelial cells treated with P.falciparum infected erythrocytes (A), and both of P.falciparum infected erythrocytes and TNF- $\alpha(B)$. The blue arrow show adhesion of P.falciparum infected erythrocytes on endothelial cells. (magnification, 1000x). 
The normal endothelial cells release low level $(+)$ of ROI in the presence of non-specific trigger, PMA. In the presence of P.falciparum infected erythrocytes or TNF- $\alpha$ or both of them some cells showed medium to high levels of ROI (++ to ++++) (figure 2). There was a significant difference in ROI expression among groups $(p=0,000)$ and using Tukey test, there was a significant difference between control cells and cells which were treated with TNF- $\alpha$ or P.falciparum infected erythrocytes or both of them $(p=0,000)$. Although release of ROI was an immunological response to parasite, it can cause apoptosis of the cells. Some cells showed shringkage phenomena with membrane blebbing. There was condensation of chromatin in nucleus of the cells.

Using immunocytochemistry some cells expressed caspase 3 in their cytoplasma especially on endothelial cells which were exposed with $P$. falciparum and TNF- $\alpha$ dose (figure 3). Caspase-3 expression found slightly on normal endothelial cells culture. This expression increased significantly on endothelial cells culture treated with both P.falciparum infected erythrocytes and TNF- $\alpha(p=0,000)$.

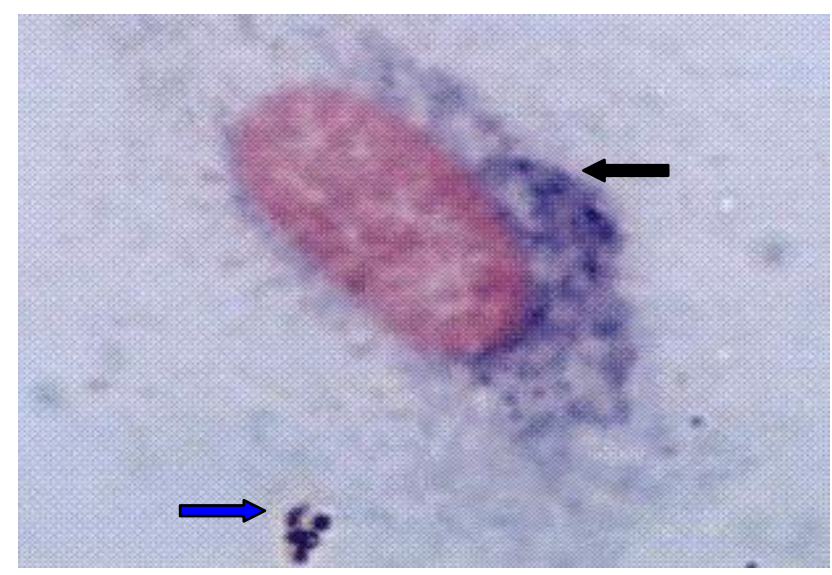

(A)

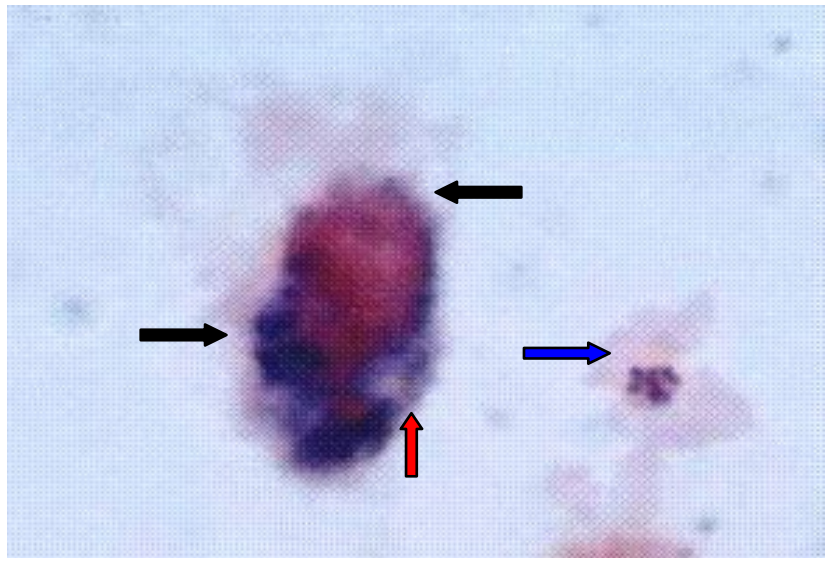

(B)

Figure 2. The black arrow show ROI production on endothelial cells treated with P.falciparum infected erythrocytes (A), and both of $P$.falciparum infected erythrocytes and TNF- $\alpha(B)$. The blue arrow show adhesion of P.falciparum infected erythrocytes on endothelial cells. The red arrow show apoptotic cells (magnification, 1000x)

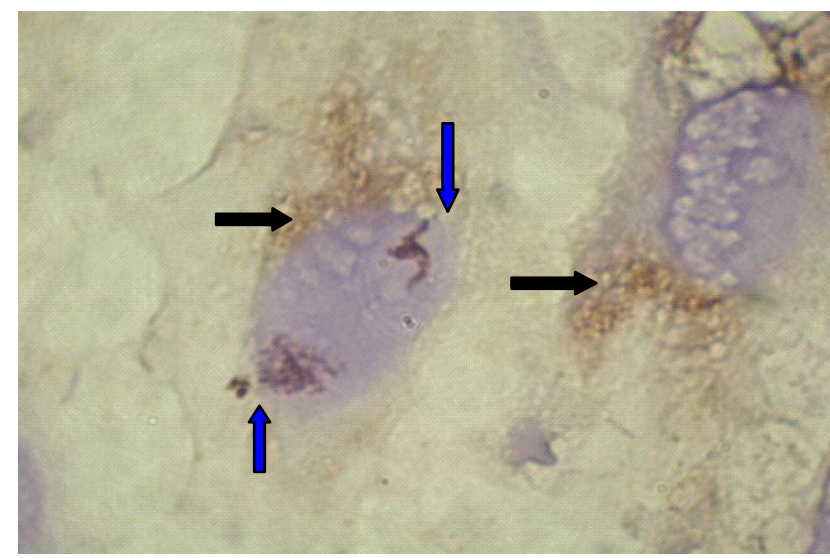

(A)

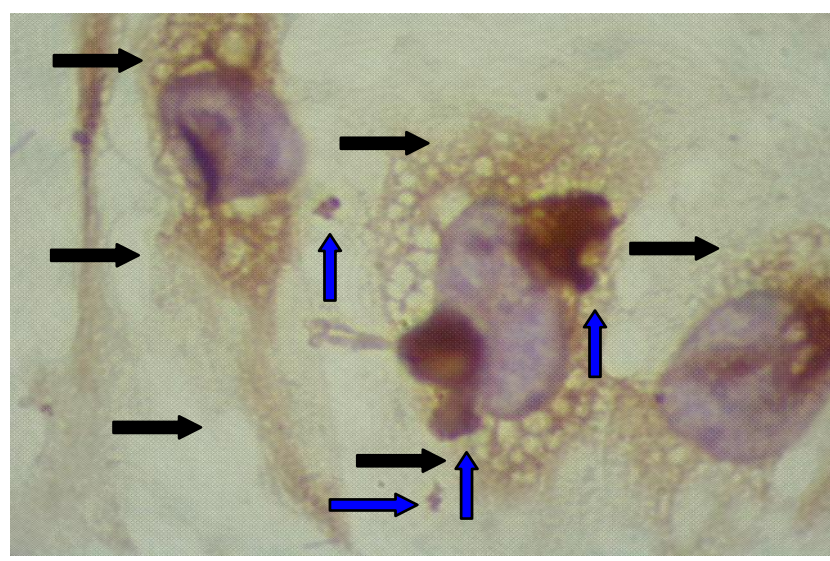

(B)

Figure 3. The black arrow show Caspase-3 expression on endothelial cells treated with P.falciparum infected erythrocytes (A) and both of P.falciparum infected erythrocytes and TNF- $\alpha(B)$. The blue arrow show adhesion of P.falciparum infected erythrocytes on endothelial cells. (magnification, 1000x) 
In other hand, referring to study on cerebral malaria patients by Weiss et al, ${ }^{11}$ it has been showed that Cerebrospinal Fluid (CSF) concentration of NO were significantly higher on cerebral malaria patients, however this was not related with local Th 1-mediated response with biopterin, neopterin and soluble Tumour Necrosis Factor Receptor p-75(TNFR-75) as parameter.

Nitric oxide production and its derivates has been suggested as molecule against malaria. The dynamic circuit for exchange of NO within the vascular explain how NO and its derivates can be proactive against malaria, however a non equilibrium between binding and unbinding NO can occur depend oxygen tensions, in this circumstances excessive localized production of NO leads to immunopathology rather than protection. ${ }^{12}$ This specific condition makes certain cells in brain can over-produce NO. ${ }^{13}$

It is not clear how NO causes cell damage or death, and it may be that it is not NO it self, but rather interaction of NO with other radicals that forms the toxic species. A second hypothesis is NO can lead to neuronal cell death and is thought to be a mechanism of damage in acute brain injury caused by stroke and also in more chronic condition including a Parkinson and dementia. ${ }^{13}$

This in vitro study might be extrapolated to acute cerebral malaria during in vivo condition. This indicates that an acute induction of iNOS expression occurs in the brain during cerebral malaria as NO may activate a number of secondary neuropathological mechanism in the brain including modulators of synaptic function. Study has been done by Maneerat, et al. ${ }^{14}$ showed iNOS expression in endothelial cells, neurons, astrocytes and microglial cells of brain tissues from cerebral malaria cases.

Falciparum malaria induces iNOS via hypoxia and inflammatory cytokines. INOS-induced NO inhibits the physiological forms of NOS (eNOS and nNOS) via negative feedback on the N-methyl-D-Aspartate (NMDA)-gated channels, resulting in the clinical picture associated with falciparum malaria, i.e. hypoglycemia, lactate acidosis, renal failure, pulmonary edema and cerebral coma. ${ }^{15}$

In animal model (CBA mice), $\mathrm{T}$ lymphocyte and Interferon (IFN)- $\gamma$ are important for development of cerebral malaria, however TNF- $\alpha$ is still critical molecule in pathology of cerebral malaria. IFN- $\gamma$ synergizes with lipopoly sacharride (LPS) and TNF- $\alpha$ enhance the superoxide anion radical production by phagocyte cells. ${ }^{16}$ This superoxide production requires a protein complex known as NADPH oxidase. Following activation of NADPH oxidase, large quantities of superoxide are produced, which are rapidly converted into hydrogen peroxide $\left(\mathrm{H}_{2} \mathrm{O}_{2}\right)$ and other Reactive Oxygen Species (ROS) that are essential for effective phagocyte microbicidal activity. However, excessive or inappropriate release of ROS may contribute to tissue injury, such as endothelial cell damage. ${ }^{17}$

Newton, ${ }^{18}$ said that a number of mechanisms may be responsible for the pathogenesis of neurological damage. It can be caused by a critical reduction in blood supply or damage by toxins such as ROS, NO or neurotoxins.

Cytoadherence of P. falciparum infected erythrocytes on endothelial cells is a key factor in development of severe malaria. This process is significantly associated with the activation of local immun on endothelial cells and release of reactive oxygen species which cause cells damage. The production of Reactive Oxygen Species, like superoxide and NO was enhanced by TNF- and may contribute cells damage like apoptosis via peroxynitrite production.

This research provide a study model to examine the pathophysiology of complicated malaria in molecular aspect. Immune local concept might be important factor beyond parasite sequestration in mediating endothelial cells damage in severe malaria. There are a number molecules by which pathological stimuli lead to apoptosis of the cells including TNF- $\alpha$, NO and other free radicals.

Cytoadherence of $P$. falciparum infected erythrocytes and TNF $\alpha$ treatment on endothelial cells can induce activation of local immune marked by increase inducible nitric oxide synthase and release of free radicals that cause cell damage.

\section{REFERENCES}

1. Turner GDH, Chuong LV, Mai NTH, Chau TTH, Phu NH, Bethell D, Wyllie S, Louwrier K, Fox SB, Gatter KC, Day NP, Hien TT, White NJ, Berendt AR. Systemic 
Endothelial Activation Occurs in Both Mild and Severe Malaria : Correlating Dermal Microvascular Endothelial Cell Phenotype and Soluble Cell adhesion Molecules with Diseases Severity. Am J Pathol 1998;152 (6):147787.

2. Turner GDH. The Malaria Research Group, Nuffield Department of Clinical Laboratory Sciences and The Oxford-Wellcome Centre for Tropical and Infectious Diseases. 2002

3. Liew FY, Cox FEG. Nonspecific Defence Mechanism: The Role of Nitric Oxide. Parasitology Today: 1990; A17-A20.

4. Schlichthele M, wahlgran M, Perlmann H, Schery A. Method in Malaria Research, third edition, MR4/ATCC, Manassas, Virginia: 2000;8

5. Udomsangpetch R, Pipitaporn B, Krishna S., Angus B, Pukrittayakamee S, Bates I, Suputtamongkol Y, Kyle DE, Whaite NJ. Antimalarial drugs Reduce Cytoadherence and Rosetting of Plasmodium falciparum. J Infect Dis 1996;173:691-8

6. Miller K. Immunocytochemical Techniques dalam Theory and Practice of Histological Techniques, edited by Bancro JD, GambleM, fifth edition, London, 2002: 421-430.

7. Supargiyono. Production, Proliferation and Functional Activities of Mononuclear Phagocytes During Plasmodium vinckei petteri Infection in Mice. Thesis submitted for the degree of Doctor of Philosophy in the Faculty of Science of the University of London. King,s College London. 1993.

8. Burgner D, Rockett K, Kwiatkowski D Nitrict Oxide and Infectious diseases, Current Topic, Arch Dis Child, 1999;81:185-8

9. Solomon HS and Dawson TM. Nitric Oxide and related Substances as Neural Messengers, Neuropsychopharmacology: The Fifth Generation of Progress, 2000:3-4, http: //www. acnp.org/g4/GN40100 0060/ CH060.html. (diakses tanggal 31 Agustus 2004)

10. Tachado SD, Gerold P, McConville MJ, Baldwin T, Quilici D, Schwarz RT, Schofield.L. Glycosylphosphatidylinositol toxin of Plasmodium induces nitric oxide synthase expression in macrophages and vascular endothelial cells by a protein tyrosine kinase-dependent and protein kinase C-dependent signaling parhway, J Immunol 1996;156:1897-1907

11. Weiss G, Thuma PE, Biemba G, Mabeza G, Werner ER, Gordeuk VR. Cerebrospinal Fluid Levels of Biopterin, Nitric Oxide Metabolites and Immune Activation Markers and The Clinical Course of Human Cerebral Malaria. J Infect Dis1998;177:10064-8.

12. Robinson AWT, Looker M. Sensitivity of Malaria Parasites to Nitric Oxide at Low Oxygen Tensions. Lancet 1998;351:1630

13. Vallance P. Nitric Oxide, Biologist 2001;48:153-158.

14. Maneerat Y, Viriyavejakul P. Inducible Nitric Oxide Synthase Expression is Increased in Fatal Cerebral Malaria (Abstract) Histopatology 2000;37:267-77

15. Ker AME, Panzer A. The Whip of Falciparum Malaria. Geneskunde Med J 2002; 44(1)..

16. Cassatella MA, Bazzoni F, Flynn RM, Dusi S, Trinchieri G, Rossi F. Molecular Basis of of Interferon-gamma and Lipopolysacharride Enhancement of Phagocyte Respiratory Brust Capability. Studies on Gene Expression of Several NADPH Oxidase Component. J Biol Chem 1990; 265:20241-6

17. Volk T, Ionannidis I, Hensel M, deGroot H, Kox WJ. Endothelial damage Induce by Nitric Oxide: synergism with Reactive Oxygen Species. Biochem Biophys Res Commun 1995;213:196-203

18. Newton RJCC. Neurocognitive sequale following falciparum malaria, Atti 30 Congresso Nazionale SIMET-SIMVIM, 8-10 November 2001 Firenze. 